Hanne Møller Andersen, PhD, is assistant professor in science education at Aarhus University. Her main research interests are students' motivation and learning in science classrooms and students' science identities. Based on many years of experience in upper secondary school as a chemistry and biology teacher, she also has an interest in the development of science teaching e.g. teacher training and intervention studies.

Lars Brian Krogh, PhD, is assistant professor at Aarhus University and has a history as a teacher of physics and chemistry in upper secondary school. Among his research interests are studies of students' engagement with science from cultural and psychological perspectives ("border crossing" and "science identities") as well as studies of how professional development can enhance science teachers' capabilities to facilitate students' interest and act as cultural brokers.

HANNE MфLLER ANDERSEN

Centre for Science Education, Aarhus University, Denmark

hanne.moeller.andersen@cse.au.dk

\title{
Science and mathematics teachers' core teaching conceptions and their implications for engaging in cross-curricular innovations
}

\begin{abstract}
Previous studies have found core teaching conceptions (CTCS) to influence teachers' actions, i.e. how they engage with new teaching practices (e.g. Lotter, Harwood, \& Bonner, 2007). This study explores typical CTCs and their subject specific nature in a sample of teachers from physics, biology, and mathematics in Danish upper secondary school. Teachers' CTCs were investigated through their essayresponses to a set of open core questions, administered through a web-platform. Results demonstrate that teachers' CTCs come in subject specific flavours, encompassing their purpose for teaching the subject, their conceptions of teaching and learning, and their conceptions of interdisciplinary teaching. It is argued that such differences shape teachers' engagement with new cross-curricular innovations in the Danish context. Assessing and addressing typical and personal CTCs are found to be crucial to a successful implementation of current reform-initiatives, for teacher training, and for self-regulated professional development among teachers.
\end{abstract}

\section{INTRODUCTION}

Teachers hold a variety of conceptions about themselves, about the world and about their professional place in the world. In particular they have conceptions about what constitutes teaching and learning in their own subject areas. These conceptions are shaped by various influences which include: personal experiences as students in the school system; enculturation into a specific discipline at university; approaches taken during teacher training programmes. Through such influences one intuitively would expect teachers' conceptions to be different for teachers coming from 
different subject backgrounds. The explorative study reported in this paper is a first attempt to identify the nature of these differences within the sciences, focusing on physics and biology, and between these sciences and mathematics, and other disciplines.

We believe that an explicit awareness of the more fundamental teachers' conceptions is important since research (e.g. Lotter, Harwood, \& Bonner, 2007; Tsai, 2007) has documented that they shape the way teachers teach, how they implement new reform-initiatives, and their participation in professional development activities. Generally speaking, curricular intentions (and reforms) are at risk whenever teachers' views are discordant with the underlying rationale of an innovation. Here, we subscribe to the view expressed by Mellado:

"The study of science teachers' beliefs or conceptions thus takes on special importance as a first step toward generating in the teachers themselves conceptions and practices better suited to the currently proposed curricular objectives." (Mellado, 1998 p.198).

The kind of teacher conceptions which we have in mind might be revealed through reflective questions such as: What defines my subject and how is it changing? What is the contribution of my subject to the schooling of students? How does it relate to the contributions from other subjects? Such conceptions are clearly a fundamental part of a teacher's professional identity, and we would argue that the capacity to develop one's own professional identity and to expand one's teaching approaches is linked to an explicit awareness of those conceptions.

In this paper the discussion of teachers' fundamental conceptions is framed by the recent introduction of new types of cross curricular innovations in the Nordic countries and elsewhere. For example, the 2005-reform of Danish Upper Secondary School (Gymnasium-stx) entails two new

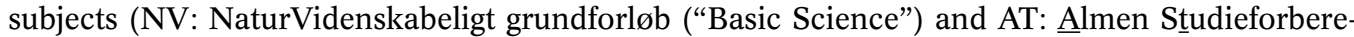
delse ("General Preparation for (Tertiary) Studies"). Both subjects involve science(s) in different ways, they are interdisciplinary by nature and they demand a thematic and collaborative pedagogy. In NV the collaboration is within science subjects, introducing students to common scientific methods and reasoning with an emphasis on how to do science. AT is even more demanding in its inclusion of knowledge from different faculties; aiming at students' ability to compare and discuss related epistemologies at a meta-level. Especially AT calls for new kinds of teacher knowledge and practice. First of all teachers need to have more articulated views on the nature of science(s) (especially epistemology) and know more about other school subjects. But it is not only a matter of knowledge. These courses also challenge more traditional teaching conceptions with their new emphases on process- and metacognitive learning objectives and their insistence on inter-disciplinarity and teacher collaboration. Similar considerations are actualized in relation to the new programme Teknologi og Forskningsloere introduced in Norway from 2007.

Important questions arising from such developments are whether teachers from different school sciences are equipped to contribute in a constructive manner. And if not, how can existing teacher training and development programmes be adjusted, utilizing and addressing teachers' conceptions?

\section{Perspectives on teacher conceptions}

Studies of teachers' conceptions about science and science teaching have developed into a major research program which is documented in the bibliography on Students' and Teachers' Conceptions and Science Education (Duit, (2007)), and in the recent review of research on science teacher knowledge (Abell, 2007). Particularly, the review is built around the notion Pedagogical Content Knowledge (PCK, Shulman, 1986), which have been extended with a belief component Orientations towards teaching (Magnusson, Krajcik, \& Borko, 1999) that encompasses (an amalgamate of) many of the teacher conceptions addressed in this paper. 
Such fundamental and personalized conceptions are found to guide teachers' decisions and actions in the classroom: "Teacher beliefs often act as "filters" through which information about students, learning and instructional strategies flow" (Lotter, Harwood, \& Bonner, 2007 p.1319). A number of studies have shown a strong relationship between core domains of teachers' conceptions and their classroom practice (e.g. Dillon, Obrien, Moje, \& Stewart, 1994; Appleton \& Asoko, 1996), while others have found a more moderate relation (e.g. Abell \& Roth, 1995; Meyer, Tabachnick, Hewson, Lemberger, \& Park, 1999).

\section{Core Teaching Conceptions}

Lotter et al (Lotter, Harwood, \& Bonner, 2007) have coined the term Core Teaching Conceptions (CTCs) to describe central beliefs influencing teachers' implementation of new inquiry based practices. Their CTC's belong to one of the following domains: views of science, purpose of education, students, effective teaching. These domains were suggested by literature studies, and the specific conceptions "emerged during the qualitative analysis of the interview and observation data" (ibid. p.1328) from a study of three teachers. The CTC's are considered "relatively stable" (ibid. p.1341) but they can interact in different ways dependent on the context. The limitation of this study clearly is its minimal sample size, which makes the resulting model exploratory and leaves the question of completeness open.

\section{Research on the subject-specificity of teachers' conceptions}

Considering the extent of research studies on teacher conceptions it is noteworthy that relatively few have investigated their subject-specificity. Säljo (Säljö, 1979) expresses reservations regarding the existence of more or less universalist conceptions of learning and argues that different educational environments might be expected to define learning according to "different socially and culturally established conventions with respect to what counts as learning" (p. 104). An obvious implication of this would be that teachers' conceptions of learning should differ from subject to subject. With this point in mind a number of phenomenographic studies (Langer \& Applebee, 1988; Marton \& Booth, 1997) set out to study differences of conceptions of learning across contexts and samples. Some authors (e.g. Pillay, 2002) emphasize the similarity of conceptions of learning found. However, the very general level of categorization of such learning conceptions tends to obscure contextual differences. Furthermore these studies identify qualitatively different categories of conceptions, not differences in frequency of specific categories. Much more context is found in Donnelly's (Donnelly, 1999) comparison of science and history teachers' educational aims/purposes. History teachers were found to have a relatively uniform set of aims while "the scientists ranged more widely" (ibid. p. 23). This conclusion may well be the result of pooling teachers from a range of distinct science subjects into a single "science" group. All in all, it seems that this research paradigm has shed only a narrow cone of light onto the subject-specific nature of teacher conceptions.

We have found no research studies looking for differences in teacher conceptions between science subjects apart from an unpublished theses by Krogh, where he uses an eight-dimensional framework TESSA ("The Ethos of School Science Analysis") for an investigation of conceptions held by pre-service teachers in physics and biology (Krogh, 2006). Even though sample sizes were moderate (physics: 28, biology: 18) several significant differences $(\mathrm{p}<0.05)$ emerged. Thus, biology teachers were found to be much more oriented towards life-world authenticity, inclusion of affective aspects and social organisation of learning than physics teachers.

\section{Research on the impact of CTCs on teachers' implementation of new curricula and participation in (cross curricular) innovation}

A central issue for the present paper is that the filtering function of teachers' core teaching conceptions constitutes a critical element in the transformation of curricular intentions to an implemented and attained curriculum, often leading to gaps between these in curricular reform. Roberts, 
in his famous paper "What counts as science education" describes how "teacher interpretation and (value laden) teacher loyalties" (Roberts, 1988 p.28) shape science education, implying that curriculum implementation (and reforms) will falter unless there is congruence between views/ conceptions held by teachers and a new curriculum. This has resonances with Lotter, Harwood \& Bonner (2007), who studied teachers' use of new inquiry based methods throughout a professional development programme: "to be successful inquiry professional development must not only teach inquiry knowledge, but it must also assess and address teachers' core teaching conceptions."

We have argued that there is a lack of research on differences between core teaching conceptions held by teachers from different sciences, and we hypothesize that some of these are likely to influence the way teachers engage in cross-curricular teaching and in implementation of curricular reform. To explore these issues this study addresses the following two questions:

1. What are the similarities and differences in the CTCs for a sample of physics, biology and mathematics teachers?

2. What are the implications of these similarities and differences for teacher engagement in cross curricular reform in particular and in professional development activities in general?

\section{Methodology}

This study was carried out in the context of a university-based in-service workshop, with the aim of preparing teachers for the new interdisciplinary course AT in upper secondary school. Most teachers had volunteered to attend the course, but some were selected by their principals. The teachers had subject backgrounds from all across the curriculum.

As a pre-reflective part of the course work, the teacher participants were asked to respond in writing to a series of web-based questions about their academic discipline and teaching and learning of the related school subject. 180 teachers from a possible total of 305 participants produced sustained pieces of writing and this became the overall sample for the study. In this respect the sample might be biased towards the more enthusiastic and progressive end of the Danish teacher group. The analysis presented in this paper is based on responses from teachers of physics (17), biology (10), and mathematics (14) with teachers in social sciences (15) and Danish language (12) being drawn upon as reference groups representing the two non-science faculties within AT.

\section{Web-based questions}

The web-based questions were made accessible to teachers through individual codes. In addition to a number of background questions (gender, place of employment (school), age, teaching experience (number of years), teaching subject etc) six open-ended 'core questions' about teachers' conceptions of their discipline and teaching of the subject were posed. Each core question had its own rubric for answering. The number and content of these core questions were determined after extensive literature studies, and though they map a larger domain than the four domains of Lotter et al we do not claim that they are a complete list. As an inspiration for teachers and to indicate the possible breadth of the core questions each was supplemented with a number of sub-questions. The phrasing of the questions reflects the meta-reflective stance to knowledge integral to the AT-context:

1. Conceptions of the (academic) discipline? What characterizes it as a particular field of study? Is it a distinct way of knowing? Do researchers apply a special kind of work process or procedures to gain knowledge? Other relevant comments?

2. Relationship between academic discipline and school subject. Do your see the school subject as a reduced, but fairly loyal version of the academic discipline? If it is an adaptation: what kind of adaptation has taken place? Do you see these adaptations as meaningful? Other important aspects? 
3. Purposes of teaching the subject in school. What reasons do you see for teaching the subject? Is it legitimized by providing particular skills, competences or a broader scientific literacy? Can its place in the curriculum be substantiated by democratic, cultural literacy, utilitarian (personal or societal) arguments? Or...?

4. Your subject versus other subjects taught in upper secondary school. In what ways does the subject you teach differ from other school subjects? In which ways can your subject interact and collaborate with other subjects in Upper Secondary School? Other considerations?

5. Learning the subject in school. What are the indications of students' learning in your subject? Is there any best way to learn the subject? What do you consider as major barriers to learning the subject?

6. Teacher role and identity. What teacher role is best suited for teaching your subject? How would you describe your relation to the discipline and subject teaching? ("It's just a professional affair"; "It's an important part of my life"; "It's an integrated part of my identity"). What kind of personal opportunities/limitations do you see in relation to teaching the subject?

\section{Analysis of teacher responses}

First, we noticed that teachers actually responded as if they had used the load of sub-questions for inspiration. Instead of answering all aspects teachers tended to "get the idea" from the first aspects and continued with related aspects they found salient.

Our first essay analysis had the individual teacher as unit, and the individual set of six core question responses were studied hermeneutically. Thus, the response to one question was allowed to support the interpretation of another. Only after all intra-case-analysis was concluded we turned to inter-case analysis for similarities and distinctions between teachers from the span of subjects. The composite teacher essays were approached with interpretive lenses afforded by a range of theoretical and empirical studies (see tables below). From these a number of tentative categories and meanings were derived from the outset, and through a process of constant comparison with the intra-case essays their usefulness and completeness were evaluated and validated. The two researchers independently categorized all essays, and subsequently met to negotiate meanings/ interpretations and compare categorizations for each teacher, in order to ensure reliability. Generally, the interrater agreement was considerable from the very beginning, e.g. Cohen's Kappa $>0.7$. However, in the worst case of mathematics Cohen's Kappa initially was 0.55 for some of the very first and premature coding. All codes and meanings were iterated until complete agreement was reached. In a few cases major changes of initial categories occurred (e.g. completely new categories had to be invented), more often meanings were adjusted. When teachers' responses included views covered by more than one category, all categories were registered. The identified categories are outlined below. However, notice that only five of the core questions are documented, since the last question on Teacher role and identity evoked little elaborate writing. We shall only be dropping a few comments from this domain. Furthermore, core questions 1 and 2 are analyzed together, as many teachers have problems to distinguish academic discipline and school subject.

\section{Purposes for teaching the subject in school}

In developing categories for teachers' views on the purposes for teaching their subject we drew on theoretical work (Driver, Leach, Millar, \& Scott, 1996) and (Sjøberg, 2005), where the following purposes were identified: economic, utility, democratic and cultural. However, since these purposes all refer to science for all, they do not include more discipline-oriented purposes. Here Roberts' classic work on curriculum emphases (Roberts, 1988) provides a relevant extension of the field. Roberts describes 7 types of curriculum emphases that are embodied in objectives of science learning. Among these there are several discipline-oriented purposes, e.g. Correct Explanations, Scientific Skill Development, and Solid Foundation. Analyzing our data with these codes, we 
Table 1. Description and indicators of categories used in the analysis of teachers' conceptions of the purpose of teaching their subject.

\begin{tabular}{|l|l|l|} 
Purpose & Description & Some Indicators \\
\hline $\begin{array}{l}\text { Everyday coping } \\
\text { (Sjøberg) }\end{array}$ & $\begin{array}{l}\text { Personal utility in } \\
\text { everyday life }\end{array}$ & $\begin{array}{l}\text { Useful knowledge about human body, health, } \\
\text { technology (energy, IT), money-transactions } \\
\text { (bank, trade), literacy.... }\end{array}$ \\
\hline $\begin{array}{l}\text { Solid foundation/ } \\
\text { Scientific Skill } \\
\text { Development } \\
\text { (Roberts) }\end{array}$ & $\begin{array}{l}\text { Basic knowledge, solid } \\
\text { foundation for further } \\
\text { study, scientific skills }\end{array}$ & $\begin{array}{l}\text { Knowledge and methods necessary for further } \\
\text { education or as a tool for other subjects (e.g. } \\
\text { physics/chemistry, economy/social science, } \\
\text { technology, medicine and ICT). }\end{array}$ \\
\hline $\begin{array}{l}\text { Societal } \\
\text { prosperity } \\
\text { (Sjøberg) }\end{array}$ & $\begin{array}{l}\text { Societal wealth and } \\
\text { development }\end{array}$ & $\begin{array}{l}\text { Science as vehicle for wealth (e.g. high } \\
\text { standards of living, source of revenue...). Science } \\
\text { and S\&T candidates necessary for development } \\
\text { and economic growth. }\end{array}$ \\
\hline $\begin{array}{l}\text { Civic literacy } \\
\text { (Sjøberg) }\end{array}$ & $\begin{array}{l}\text { Knowledge about } \\
\text { socio- scientific issues. } \\
\text { Democratic influences } \\
\text { and citizenship. }\end{array}$ & $\begin{array}{l}\text { Capacity to understand, discuss, and critically } \\
\text { evaluate Socio-Scientific Issues (e.g. climate, } \\
\text { gene-technology, energy-production, limitations } \\
\text { of societal models...), including media- } \\
\text { representations. Engage students in societal } \\
\text { discussions and decision-making. }\end{array}$ \\
\hline “Bildung” & $\begin{array}{l}\text { Knowledge leading to } \\
\text { a personal enrichment } \\
\text { and development. }\end{array}$ & $\begin{array}{l}\text { "Habits of mind" (Dewey) (wonder, logical } \\
\text { thinking, critical reflexivity), autonomy \& } \\
\text { identity, understanding our place (in time/space, } \\
\text { history \& culture), and science as culture. }\end{array}$ \\
\hline $\begin{array}{l}\text { Not oriented towards specific instrumental } \\
\text { purposes. }\end{array}$ \\
\hline
\end{tabular}

found no instances of Correct Explanations, and in most cases characteristics of Scientific Skill Development and Solid Foundation were inseparable. Table 1 presents the final categories for analyzing teachers' conceptions of purposes for teaching their subject.

\section{Conceptions of teaching/learning}

Several researchers have found that teachers' conception of good teaching is strongly related to their ideas about how students learn (Boulton-Lewis, Smith, McCrindle, Burnett, \& Campbell, 2001; Koballa, Graber, Coleman, \& Kemp, 2000), so in our description and analysis we have chosen to group the two together. Our evaluation of teachers' conceptions of teaching and learning are based on their responses to core questions 4-6. Our analysis is inspired by (Tsai, 2002), who has identified Traditionalist, Process, and Constructivist teacher positions in relation to teaching and learning. However, since consistent Constructivists were rare in our sample we invented supplementary categories to help us differentiate aspects of the other positions, e.g. explicate Student Centred and Subject Centred aspects. We found it relevant to indicate whether students' abilities/ interests or subject structure/curriculum demands were central in the remarks about content. Similarly, we indicated whether students or teacher were given major agency in the teachers' descriptions of pedagogy. Finally, we registered if teachers described deliberate shifts in agency (e.g. handing over agency to students) as their lessons develop. Table 2 presents categories used for an analysis of teachers' conceptions of teaching and learning. 
Table 2. Description and indicators of categories used in the analysis of teachers' conceptions of the teaching/learning process.

\begin{tabular}{|c|c|c|}
\hline Teaching/learning & Description & Some indicators \\
\hline $\begin{array}{l}\text { Traditionalist } \\
\text { teacher } \\
\text { (Tsai) }\end{array}$ & $\begin{array}{l}\text { Emphasis on knowledge as a } \\
\text { product to be transferred and } \\
\text { acquired by the students }\end{array}$ & $\begin{array}{l}\text { Transferring knowledge, firm answers, } \\
\text { clear definitions, presenting truth and } \\
\text { facts, giving explanations. }\end{array}$ \\
\hline $\begin{array}{l}\text { Process oriented } \\
\text { teacher (Tsai) }\end{array}$ & $\begin{array}{l}\text { Emphasis on mastery of } \\
\text { disciplinary processes and } \\
\text { procedures }\end{array}$ & $\begin{array}{l}\text { Scientific methods, problem-solving, } \\
\text { Experimental knowledge }\end{array}$ \\
\hline $\begin{array}{l}\text { Constructivist } \\
\text { teacher } \\
\text { (Tsai) }\end{array}$ & $\begin{array}{l}\text { Emphasis on knowledge as } \\
\text { a personal construction of } \\
\text { understanding }\end{array}$ & $\begin{array}{l}\text { Helping students to construct, } \\
\text { discussion and cooperative learning, } \\
\text { students' alternative conceptions, meta- } \\
\text { cognition, critical thinking }\end{array}$ \\
\hline $\begin{array}{l}\text { What decides } \\
\text { content? }\end{array}$ & $\begin{array}{l}\text { Are students' or subject } \\
\text { demands emphasized in } \\
\text { teachers' talk of content and } \\
\text { curriculum as part of the } \\
\text { teaching/learning process? }\end{array}$ & $\begin{array}{l}\text { Subject centred: e.g. emphasis on } \\
\text { curricular demands or subject matter } \\
\text { structure... } \\
\text { Student centred: e.g. students' abilities, } \\
\text { alternative frameworks, experiences, } \\
\text { interests... }\end{array}$ \\
\hline $\begin{array}{l}\text { Who has major } \\
\text { agency? }\end{array}$ & $\begin{array}{l}\text { Who is given major agency } \\
\text { in teachers' description of } \\
\text { teaching/learning processes } \\
\text { and pedagogies facilitating } \\
\text { learning. }\end{array}$ & $\begin{array}{l}\text { Teacher Agency: e.g. lecturing, teaching } \\
\text { at the blackboard, students being } \\
\text { introduced to...; teacher has to go over } \\
\text { content... } \\
\text { Student Agency: e.g. group work/ } \\
\text { being supervised by teacher, students' } \\
\text { presenting, doing practicals, asking } \\
\text { questions, solving problems }\end{array}$ \\
\hline Shifts in agency? & $\begin{array}{l}\text { Do teachers mention deliberate } \\
\text { shifts in agency as lessons } \\
\text { progress? }\end{array}$ & $\begin{array}{l}\text { From teacher to student agency - or } \\
\text { vice versa? Other? Flexible? }\end{array}$ \\
\hline
\end{tabular}

\section{Conceptions of academic discipline and related school subject}

Traditionally most science teachers have focused on students' learning of the products of science (theories, laws and concepts), but lately there has been an increased focus on students' learning about science processes, being a central component in "scientific literacy" oriented curricula (Dillon, 2009). Tsai has in his study of teachers' conceptions of their discipline identified a category of Traditionalist having a product oriented view and a category of Process orientated having a process oriented view (Tsai, 2002; Sjøberg, 2005). In the present study conceptions of the discipline and/or school subject are merged since teachers' responses showed little awareness of the distinction between the two.

The differentiation between process and product orientation is meaningful for most teachers, but not for teachers of mathematics, because they usually describe their subject in different terms. To catch mathematics teachers' views we draw on Paul Ernest's description of mathematics teachers as being oriented towards 'conceptual understanding', 'problem posing and solving' and 'skills 
Table 3. Description and indicators of categories used in the analysis of teachers' conceptions of their academic discipline and/or the distinction between discipline and school subject.

\begin{tabular}{|l|l|l|}
$\begin{array}{l}\text { Academic discipline } \\
\text { and/or school subject }\end{array}$ & Description & Some indicators \\
\hline $\begin{array}{l}\text { Product orientation } \\
\text { (Tsai; Sjøberg) }\end{array}$ & $\begin{array}{l}\text { Focus on products and } \\
\text { established knowledge }\end{array}$ & $\begin{array}{l}\text { Sciences: Natural theories \& laws. Science as } \\
\text { exact/Truth/Facts. Explanations of nature. } \\
\text { Universal character of knowledge. } \\
\text { Other: Focus on texts, grammar ... }\end{array}$ \\
\hline $\begin{array}{l}\text { Process orientation } \\
\text { (Tsai; Sjøberg) }\end{array}$ & $\begin{array}{l}\text { Focus on the process } \\
\text { of how science works } \\
\text { and creation of new } \\
\text { knowledge }\end{array}$ & $\begin{array}{l}\text { Sciences: Scientific method(s). (Controlled) } \\
\text { Experiments. Knowledge/hypotheses are } \\
\text { tested. Procedures (e.g. replicability)... }\end{array}$ \\
\hline $\begin{array}{l}\text { Skills mastery } \\
\text { orientation (Ernest) }\end{array}$ & $\begin{array}{l}\text { Instrumentalism, use of } \\
\text { tools and techniques in } \\
\text { an educational setting }\end{array}$ & $\begin{array}{l}\text { Mathematic as tool/support for other } \\
\text { subjects. Application. Training of skills. }\end{array}$ \\
\hline $\begin{array}{l}\text { Distinction between } \\
\text { academic discipline } \\
\text { and school subject }\end{array}$ & $\begin{array}{l}\text { Do teachers see any } \\
\text { distinctions between the } \\
\text { two? }\end{array}$ & $\begin{array}{l}\text { Same essence: } \\
\text { True version: No distinction in purpose, } \\
\text { nature, or methods. True - but content- }\end{array}$ \\
\hline & $\begin{array}{l}\text { reduced. True, but complexity adjusted. } \\
\text { Different in essence: }\end{array}$ \\
\hline & $\begin{array}{l}\text { Differences related to purpose, nature, } \\
\text { methods, content }\end{array}$ \\
\hline
\end{tabular}

mastery' (Ernest, 1989). Ernest associates the first with a "unified body of certain knowledge" which makes it a product-orientation, while the 'problem posing and solving' is a process-orientation. New, however, is the 'skills mastery-orientation' with its instrumental view. Table 3 presents the categories used.

\section{Conception of interdisciplinary teaching and the role of the subject}

Teachers' conceptions of interdisciplinary teaching and the role played by their subject pedagogy (e.g. subjects in sequence, parallel or integration (Hurley, 2001)). In answering the question "In which ways can your subject interact and collaborate with other subjects in Upper Secondary School?" teachers took different perspectives. Some of the teachers focused on the contribution and benefits (application, aims) of their subjects, while others referred to interdisciplinary themes, experiences and aims.

\section{FINDINGS}

We present and discuss our results for teachers' CTCs in accordance with the structure of the preceding paragraph: 1) purposes for teaching the subject in school; 2) teachers' conceptions of teaching/learning; 3 ) teachers' conceptions of the academic discipline and the relationship between school subject and academic discipline; 4) teachers' conceptions of interdisciplinary teaching and ways in which their subject could interact with other subjects. 
Table 4. Description and indicators of categories used in the analysis of teachers' conceptions and attitudes towards interdisciplinary teaching.

\begin{tabular}{|l|l|l|}
$\begin{array}{l}\text { Interdisciplinary } \\
\text { teaching }\end{array}$ & Description & Some indicators \\
\hline $\begin{array}{l}\text { Inclination towards } \\
\text { interdisciplinary } \\
\text { teaching }\end{array}$ & $\begin{array}{l}\text { Positive or negative attitude } \\
\text { in relation to interdisciplinary } \\
\text { teaching }\end{array}$ & $\begin{array}{l}\text { Negative: No mentioning } \\
\text { Positive: Mentioning themes/cases } \\
\text { suitable for interdisciplinary teaching }\end{array}$ \\
\hline $\begin{array}{l}\text { Perspective on } \\
\text { Interdisciplinary } \\
\text { teaching }\end{array}$ & $\begin{array}{l}\text { Internalist subject perspective } \\
\text { or integrated perspective }\end{array}$ & $\begin{array}{l}\text { Subject perspective. Mentioning of } \\
\text { specific subject matter and skills. } \\
\text { Subject enhancing collaboration with } \\
\text { subjects from same faculty. Shared } \\
\text { teaching of common methods. }\end{array}$ \\
\hline & $\begin{array}{l}\text { Integrated perspective. Mentioning } \\
\text { of themes and project drawing } \\
\text { knowledge from more than one faculty } \\
\text { e.g. Cosmology, Self-esteem and plastic } \\
\text { surgery, Creationism }\end{array}$ \\
\hline
\end{tabular}

\section{Purposes for teaching the subject in school}

The teachers identified a range of purposes for teaching their individual subjects. The overall analysis reveals that most of the science teachers (some $60 \%$ ) stated more than one purpose, while teachers in social science and Danish tended to restrict themselves to a single purpose. Details are shown in the figures below where the teaching purpose-profile for each subject is inserted as a mini-figure, allowing individual scrutiny and comparison. In the mini-figure each category of purposes is represented by a corner, and the axes indicate the share of teachers within a given subject that mentions the specific purpose. As can be seen from these figures the science teachers' purpose-profiles come out very differently for biology and physics and these both differ from other subjects.

The profile for physics teachers appears to be relatively homogeneous across different purposes and strikingly they are the only group of science teachers in our sample to display this trend. In this respect our study indicate that the previous study of (Donnelly, 1999) is likely to overlook significant differences. Interestingly, our physics teachers most frequently refer to 'Bildung' as a central purpose, contrasting with biology teachers who refer to civic literacy and students ability to understand and discuss socio-scientific issues. A typical biology teacher writes:

"Many of the topics that we engage with in biology are discussed in the media on a daily basis, and that's exactly why students should learn to respond to such issues and participate in related debate" (teacher 2)

The mathematics teachers have the usefulness of mathematical skills in relation to other education (Solid foundation) as their main argument. However, often this is combined with a particular formative Bildung-orientation, associating autonomy and enrichment with logical reasoning.

"Students must learn mathematics, primarily because mathematics has huge applicability within science, economy, social science, technology, medicine and ICT, but also because it is important to learn to analyze and deduce complex problems and get a sense of proportions" (teacher 60). 


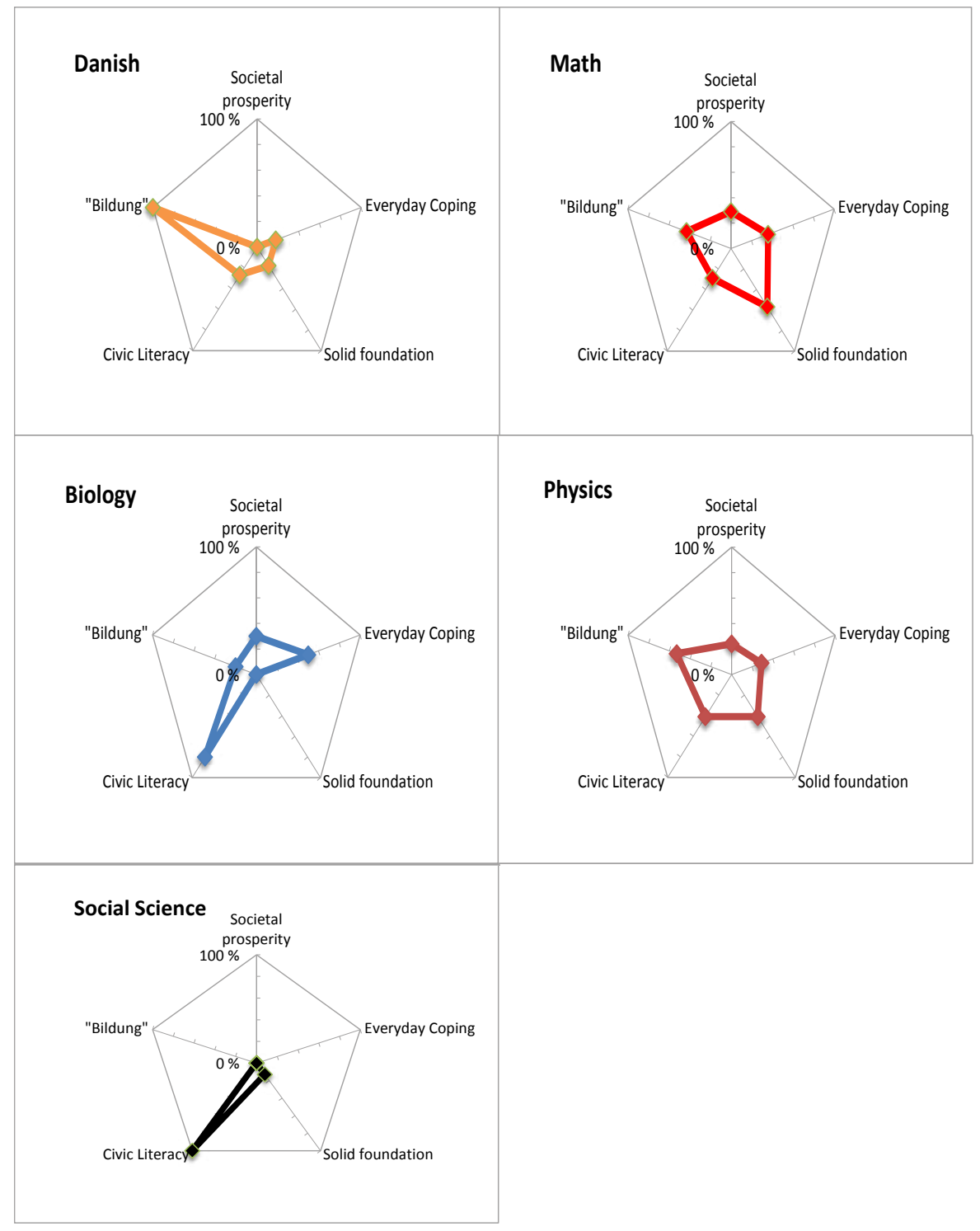

Figure 1 The distinct profiles of Teaching Purposes for teachers from various subjects (upper secondary school).

Characteristically, teachers in Danish and social science downplayed instrumental purposes, like societal prosperity, basic skills or everyday coping. Instead Danish teachers emphasised students' 'Bildung', as illustrated:

"...it takes awareness of language and communication, and analytical sense across different social contexts to gain a better understanding of the lives of other people, and hopefully also more tolerance and interest. In addition, historical insight into cultural trends is an essential precursor for participation and understanding of contemporary cultural trends and orientations." (teacher 83) 
The social science teachers were more focused on students becoming informed citizens and their ability to take active part in decision-making and democracy:

"I suppose social science gains a particular democratic value by introducing students to matters of the society and what influences them, thereby contributing to (active) citizenship" (teacher 69).

In this way teachers' conceptions of the purpose of learning their subjects clearly turn out to have subject-specific flavours. In different ways these relate to the rhetoric of the 2005 Danish reform of Upper Secondary school (e.g. Danish Minister of Education at first reading of reform bill, 31 October 2003), where science in general was designated as an equal contributor to 'Bildung' and civic literacy. Thus from our analysis, biology teachers along with the teachers in social science are more likely to be oriented towards students developing civic literacy, while physics teachers tend to be the more 'Bildung'-oriented science teacher group.

\section{Conceptions of teaching/learning}

Most science and math teachers (app. 60\%) emphasised the importance of students taking an active part in teaching and learning activities (e.g. problem solving and practical work), but there is a difference between biology and physics/mathematics teachers. Many of the physics/mathematics teachers (app. 30\%) conceptualised the optimal way of teaching as a sequence, initiated by the teacher's explanation of important subject matter, followed by students working on related problems. This telling-applying approach is illustrated by a physics teacher's description of the best way to teach and learn physics:

"[Students] are presented with physics explanations, laws and interesting phenomena that they might already have encountered. This is followed by student-work on similar "cases" where students try to find solutions and explanations. In the end students make a presentation of their work either orally or in written text" (teacher 19)

Biology teachers tended not to envision this kind of standard procedure; instead they mentioned variation as an important element and several biology teachers pointed to the fact there is no best way of teaching biology; the optimal way depends on the given situation and the students present in the classroom (a view shared by some 15\% of the sample). One biology teacher wrote about good teaching:

“...variation, serious consideration of students' questions, an understanding of students' points of departure and serious consideration of the differences among students" (teacher 9)

In contrast to physics/mathematics teachers, biology teachers did not mention teachers lecturing when they wrote about the best way to learn biology and they were less focussed on students' capability to do problem solving, which might be explained by a more widespread use of problem solving in the evaluation of students' abilities in mathematics and physics.

Teachers' conceptions of students typically enter this study through their writing about barriers to teaching/learning. Teachers from all three subjects (a minority) mentioned students' lack of motivation and effort as an important hindrance for learning. The most notable difference is that a few biology and physics teachers (6 teachers in total) mentioned students' alternative frameworks as potential barriers for students learning while mathematics teachers tended to focus on students' lack of ability to handle abstract thinking (6 teachers). 


\section{Conceptions of discipline}

One remarkable finding of this study is that many teachers had great difficulty in distinguishing between the academic discipline and related school subject, which makes it difficult to report on teachers' conceptions of their discipline. About 40\% of the teachers responded to the question on characteristics of their academic discipline with reflections clearly referring to their school subject. This appeared to be a general trend, across disciplines, and can be illustrated by the following;

"Biology is a subject based on experiments. The students learn to combine theory and practice. The practical work is an important part of biology teaching..." (teacher 7)

We have considered the possibility that the apparent mix-up could be a symptom of teachers' misunderstanding our rather academic 'core-question'. Actually, a few teachers do express that this first 'core-question' is hard to understand, and there is a few blanks. However, the share of such responses is far below the share of 'non-distinguishers'. Most importantly, asking to the 'Relationship between academic discipline and school subject' we find additional evidence that the blurring between academic discipline and school subject is not an artifact. Teachers' responses here were analyzed and quantified, with the results shown in Figure 2.

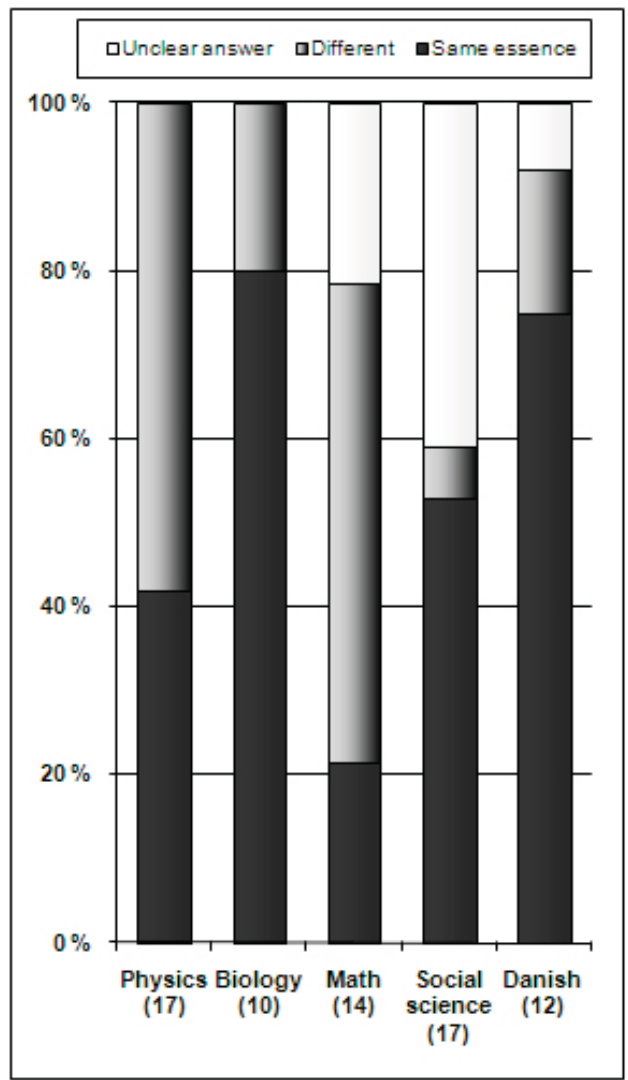

Figure 2. The relation between school subject and academic discipline (numbers of teachers are indicated in parentheses). 
Explicitly asked 50\% of the teachers maintain that their school subject is in essence just like the corresponding academic discipline. Only $1 / 5$ of the total sample of teachers provides substantial arguments for a clear distinction.

The subject related response of In-essence-the-same appears clearly from Figure 2. Almost 80\% of the teachers in biology considered school science to be essentially the same as academic science, while only $20 \%$ of the math teachers found it to be the case. Many biology teachers described school biology as being a fairly close to academic science, as can be seen in the following:

"School biology is a true version of academic biology. Central to the teaching of biology is the scientific method, which is what aligns it with the academic discipline." (teacher 11)

For this teacher scientific method acts as connector between school biology in upper secondary school and academic biology. In addition the relevance of biological knowledge in relation to social scientific issues - both at academic and school level - appeared as a reason for this blurring. By way of contrast, most mathematics teachers saw school and academic mathematics as essentially different enterprises, a view backed up with reflections on the nature of school mathematics as mainly being focused on practical uses, while academic mathematics is more concerned with developing mathematical proofs and models. The response from a typical mathematics teacher illustrates the point:

"Mathematics in schools lacks some of the aspects of disciplinary mathematics. E.g.: there is not much proof and deduction left. Mathematics in upper secondary is more like a tool to be applied in other subjects: Pick the right formula, insert some numbers and calculate or let a program do the calculation for you. This situation may be caused by the way written (national) exams are configured. I think, you should be able to find mathematical domains, where calculators are downplayed and proof and logical reasoning are at the core." (teacher 51)

Mathematics teachers frequently referred to limitations in students' capabilities of abstract and logical thinking, when they argued for a distinction between school and academic science.

A high proportion of teachers in Danish language and social science considered the school subject and academic discipline to be in essence the same. These teachers were aware of different levels of subject matter knowledge, but they had a notion of methods and procedures being the same in upper secondary and at university level.

\section{Product-Process emphasis}

Characterizing their academic and/or school subjects most teachers mentioned processes, products, or both. Figure 3 shows how process- and product-emphases were realised across subjects.

Teachers' characterizations of their subjects in terms of products and/or process do differ. It is a general trend that the science teachers conceptualised their subjects with a strong emphasis on processes. In contrast to other groups, the mathematics teachers had a strong emphasis on skills mastery, e.g. almost $60 \%$ of this group of teachers drew attention to mathematical skills. One of the mathematics teachers characterised his subject in the following way:

"[Mathematics] provide a service and methods to other subjects (e.g. statistic, differential calculus, mathematical equations, linear regression, exponential growth etc.)" (teacher 52)

Teachers in social science primarily conceptualised their subject in terms of products, which is a little surprising: one might expect more of a process-orientation with their strong purpose-orientation towards Civic Literacy. Danish teachers balanced products and processes in their responses. 


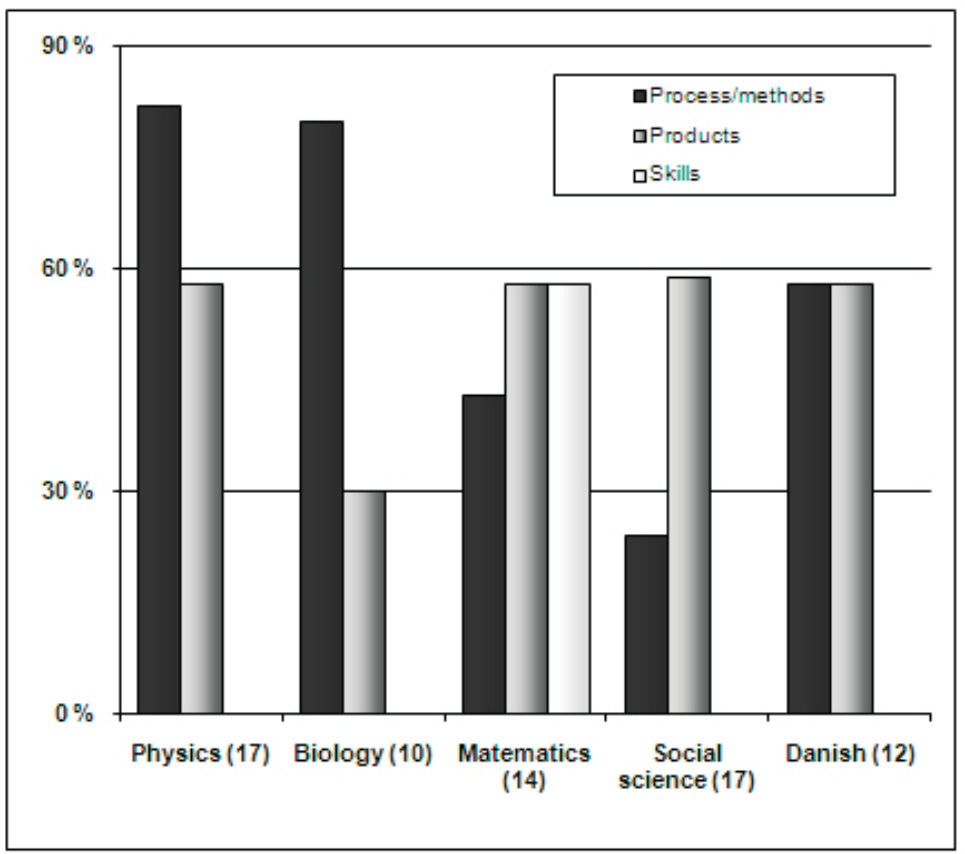

Figure 3. Teachers' mentioning of product- and process aspects in their description of subjects/ disciplines.

An interesting process-related aspect is that more than half of the physics teachers made reference to 'The Scientific Method' (singular form). Generally, very few of the teachers expressed philosophy of science-informed views about the nature of science, but a closer inspection of the essays reveals that conceptions of The Scientific Method are related to Popperian beliefs in hypotheticaldeductive method and falsification (e.g. Godfrey-Smith, 2003). A similar "falsificationist" view of science can be found in the curriculum-description for all science subjects in upper secondary. Apparently, the physics teachers were easily aligned with such conceptions. Across the sciences some instances of logical positivism have been found in the essays, while 'the sociological turn' (e.g. Kuhn, Latour, ibid.) in philosophy of science is absent from the sample.

\section{Conceptions of interdisciplinary teaching and the role of the subject}

With a few exceptions (4\%) all the participating teachers expressed a positive view on interdisciplinary teaching and collaboration with other subjects. However, most of the teachers wrote about collaboration from a subject-oriented perspective. Thus a physics teacher wrote:

"Physics can contribute to the construction of models (e.g. models of climate, energy supply) which acts as a qualified basis for interdisciplinary teaching with other subjects, like social science etc. In particular, physics can collaborate with mathematics, chemistry, biology (the other exact subjects)." (teacher 13).

From a subject-oriented perspective interdisciplinary work should be grounded on traditional subject matter but with the extension of some extra perspectives. Only a smaller fraction (approx. $15 \%$ ) of science teachers described interdisciplinary projects as an integration of subjects around real-life-issues. Thus a biology teacher wrote: 
"Collaboration with science in general is extended. Gradually, they tend to be doing only biological oriented practicals. Physical education is a natural partner, in topics like performanceenhancing, health aspects and prevention of injuries. Previously, we have made course-modules on anorexia, plastic surgery, self-esteem etc. with the subject Danish as partner. Geography is the abiotic part of biology, which makes it a frequent partner. All carbon-chemistry (organic) is taught within biology, but in-organic parts of chemistry provide useful support, as does to a lesser extent mathematics, when a problem calls for calculation..." (teacher, 10)

The fact that only a few science teachers mentioned topics outside their traditional subject as interesting in relation to interdisciplinary teaching is probably linked to the fact that very few of the teachers saw topics relating to students' interests and everyday life as factors of importance for students' learning.

Depending on the subject, teachers have different conceptions of interdisciplinary teaching. One extreme is provided by the mathematics teachers where not even a single teacher stated a subjecttranscending integrated perspective. The other extreme is social science and Danish teachers, who almost exclusively expressed an integrated perspective - only $10 \%$ of these teachers identified their main focus as subject learning. Biology and physics teachers positioned themselves somewhere in between, approximately $50 \%$ of teachers in these subjects expressed views corresponding with a subject-oriented perspective; while $25 \%$ expressed views corresponding with an integrated position.

\section{IMPLICATIONS FOR TEACHER ENGAGEMENT IN CROSS-CURRICULAR REFORM}

We will now discuss our empirical findings against the demands embedded in the recent reform of upper secondary school ('Alment gymnasium', stx) - in particular its new emphasis on interdisciplinary teaching and meta-perspectives on knowledge (e.g. science as a particular form of knowledge with certain strengths and limitations). Our analysis has established some characteristics shared by the participating science teachers and some more subject specific 'flavours'. Both elements will be of importance to teachers' engagement in the reform.

\section{Shared CTCs of importance for teachers' engagement in reform}

All teachers in this study have positive attitudes towards one or more kinds of interdisciplinary teaching, and from a reform-implementation perspective this is quite promising. However, only $15 \%$ of the science teachers expressed a view where real-life issues and problems were central for students' learning, as they are intended to be in the new interdisciplinary curricula. Furthermore, many science and all math teachers did not transcend a subject perspective when they wrote about interdisciplinary teaching. This focus on traditional subjects tend to complicate teachers' engagement with the reform, and may contribute to the identified dislike of AT experienced by many science teachers (Danmarks Evalueringsinstitut, 2009b).

Application of subject matter knowledge (SMK, Shulman, 1986) is an important indicator of learning in all subjects. So, cross-curricular innovations like AT may be seen as a new arena to unfold applications of SMK. However, in AT applications are determined by the problem being investigated instead of subject demands. This may frustrate the more subject-oriented teachers.

Many teachers do not distinguish between academic disciplines and school subjects, and only a few acknowledge the different institutional aims, which is an unsettling unreflective starting point for teachers work with AT. Furthermore, many science teachers will find it difficult to include aspects of philosophy of science in their teaching of AT since only a few expressed philosophy of science informed and contemporary views on the nature of science. This corresponds with the need to improve teachers' insights in this area already stressed in the report evaluating the first cycle of AT (Danmarks Evalueringsinstitut, 2009a, p.28) 
Finally, many upper secondary science teachers tend to build their professional identity around their teaching subjects: some $60 \%$ of the teachers in our sample explicitly make such 'tribal'identification. Teachers in Danish upper secondary school have as part of their education been through an enculturation process into academic science, and it has shaped their identities. This ensures engagement in traditional subject teaching, but may counteract interdisciplinary teaching, challenging both their traditional CTCs and their subject-based identity.

\section{Subject-specific CTCs and reform engagement}

An important finding from this exploratory study is that science teachers CTSs have subject specific 'flavour', and we hypothesize that some of the differences in CTCs will influence the way teachers' from various subjects will engagement in cross-curricular collaborations:

1. Different conceptions of purpose may constitute barriers to interdisciplinary collaboration, assuming that cross-curricular teaching of a more integrated nature can only be sustained when the participating teachers have similar conceptions of purposes of teaching their subject:

- Biology teachers have a clear civic literacy-orientation in their purposes, which seem to provide a perfect grounding for working with socio-scientific issues, real-life risk and decision-making and the relation between evidence and claims to knowledge. With this emphasis biology teachers more or less coincide with the emphases of teachers from social science - and obviously these two subjects would be a convenient match for crossfaculty cooperation in subjects like AT.

- The mathematics teachers emphasise the purpose of providing a 'solid foundation' for other subjects and further studies. This could be read as an invitation to cross-curricular collaboration, but at the same time these teachers only speak of interdisciplinary teaching from a subject-oriented perspective. With this narrow emphasis, mathematics teachers might have considerable difficulty in engaging in the reform initiatives.

- The physics teachers appear to have a broader range of more moderate emphases, which suggests that they could engage pretty flexibly in cross-curricular teaching and still have priorities fulfilled. Physics teachers in this sample are the closest match to teachers of Humanities (Danish, in the sample) in their orientation towards Bildung. This broad orientation among physics teachers of the sample may be seen as a response to decades of criticism of physics teaching and physic's struggle for legitimization.

2. When it comes to differences in curriculum emphasis and pedagogy other CTCs are actualized:

- The profound blurring of academic discipline and school subject found among many teachers is particularly strong among biology teachers. It may be related to the origin of biology as Natural History, where academic fields and forms of knowledge were only weakly demarcated from everyday knowledge. This would construe biology as more inclusive than the other science subjects.

- In this study very few science and mathematics teachers state that learning is facilitated by content being relevant to students' everyday lives and interests. Relevance to students is therefore not likely to be prioritized when science teachers select content for interdisciplinary teaching. In contrast half of the social science teachers identify student relevance as an important aspect of learning.

- Only a few teachers in our sample can be characterized as constructivists. But teachers from science and mathematics emphasized the value of student activities, and their commitment to interdisciplinary teaching will probably depend on the possibility to integrate subject-relevant activities.

- Problem-solving ability is an indicator of students' learning and an important aspect of physics and mathematics in school (closed problems). In other words: these subjects have a shared interest which might be cultivated in collaboration between the two. Biologists, on the other hand, tend to prefer a 'softer' pedagogy including open 
tasks and discussions (students formulating problems, having discussions and producing written responses), and some biologists also mention students' affective learning outcomes. These differences among physics and biology teachers match the findings in Krogh (2006). Biology teachers' CTCs seems to comply well with conceptions held by teachers in social science and Danish, indicating a common ground for integrating pedagogies e.g. project-work.

- Most teachers of physics (and some mathematicians) describe a lesson structure with a gradual movement from transmission of knowledge ("telling") towards more studentcentred activities ("application"). This pattern is not apparent in the responses from biology teachers. This telling-applying-approach is not compatible with a teaching based on students' project work; it would only be suitable for cross curricular collaboration based on parallel teaching.

\section{Changing CTCs in favour of teachers' reform engagement}

Our study has identified areas where the CTCs of science and math teachers are discordant with conceptions embedded in the 2005 reform. The critical consideration now is how teacher development can be achieved to facilitate the implementation of reform intentions.

Teachers' CTCs may be made available to their own reflection with a methodology like the one applied in this exploratory study. Writing essay-responses to fundamental core questions serves the purpose of explication of CTCs and provides a starting point for reflection and/or discussion in groups of teachers and/or teacher-trainers. The exact number and phrasing of core questions may be adjusted, but it might be useful to maintain the key-elements of the present work, making it possible to use our analytical categories and results as a point of reference for joint analysis and discussion.

CTCs are central parts of science teachers' belief-system, and as such they may be difficult to change. Inspired by the research on cognitive (conceptual) change we would suggest confrontation as another strategy to try to improve teachers' CTCs. Helping teachers to experience a tension between their CTCs and the intentions outlined in the reform initiative, may establish a need and initiate a process leading teachers' towards a revision of their CTCs. Real change, however, should only be expected when new conceptions are perceived plausible and proven fruitful in the teacher's own practice. The complex interaction between professional experimentation and belief change must be utilized for this purpose (Clarke \& Hollingsworth, 2002).

Information on teachers' CTCs can be used to target developmental activities in relation to the curriculum reform. The analysis presented in this paper suggest a number of subject specific issues, e.g. that physics teachers might benefit from courses in how science really works, while biology teachers in particular should be given more opportunity to reflect on the relationship between biology as an academic discipline and a school subject, and mathematicians' internalist views of cross-curricular participation should be challenged.

\section{CONCLUDING REMARKS}

This study has expanded previous studies on teachers' CTCs in the sense that it both explores 'the whole range' of CTCs and does that across the curriculum. The broad approach has provided insights into (science) teachers' CTCs and particularly it has substantiated subject specific aspects of these.

Teachers' adaptation and implementation of new curricula is shaped by their central beliefs, and we have discussed how general and subject specific CTCs might interfere with new intended curricula of upper secondary school. Some evidence of this actually happening has been indicated. 
Finally we have suggested simple methods and strategies to improve teacher awareness and reflexivity in relation to (their own) CTCs. These might be a useful starting point from a personal teacher development perspective as well as an "enact-the-change-policies-of-the-system"-perspective (Clarke \& Hollingsworth, 2002). Fundamentally, we believe that only by assessing and addressing CTCs in addition to other aspects of pedagogic content knowledge and subject matter knowledge we will be able to meet the call for a "Renewed pedagogy for the future of Europe", including the demands of the new Danish reform initiatives.

\section{ACKNOWLEDGEMENT}

The authors would like to acknowledge Professor Phil Scott, University of Leeds, for his critical and helpful comments that greatly improved the manuscript.

\section{REFERENCES}

Duit, R. (2007): Bibliography: Students' and Teachers' Conceptions and Science Education (STCSE). (2007). http://www.ipn.uni-kiel.de/aktuell/stcse/stcse.html .

Abell, S. (2007). Research on Science Teacher Knowledge. In S.Abell \& N. Lederman (Eds.), Handbook of Research on Science Education (pp. 1105-1149). Mahwah, New Jersey: Lawrence Erlbaum Associates, Publishers.

Abell, S. K. \& Roth, M. (1995). Reflections on A 5Th-Grade Life-Science Lesson - Making Sense of Childrens Understanding of Scientific Models. International Journal of Science Education, 17, 59-74.

Appleton, K. \& Asoko, H. (1996). A case study of a teacher's progress toward using a constructivist view of learning to inform teaching in elementary science. Science Education, 80, 165-180.

Boulton-Lewis, G. M., Smith, D. J. H., McCrindle, A. R., Burnett, P. C., \& Campbell, K. J. (2001). Secondary teachers' conceptions of teaching and learning. Learning and Instruction, 11, 3551.

Clarke, D. \& Hollingsworth, H. (2002). Elaborating a model of teacher professional growth. Teaching and Teacher Education, 18, 947-967.

Danmarks Evalueringsinstitut, E. (2009a). Almen studieforberedelse på stx og studieområdet på hhx og htx - det første gennemløb 2005-2008 [General Preparation for Studies within Stx and Htx Gymnasium - First Circle 2005-2008]. København: Danmarks Evalueringsinstitut [The Danish Evaluation Institute]. (in Danish)

Danmarks Evalueringsinstitut, E. (2009b). Det tekniske og naturvidenskabelige fagområde på htx og stx. Evaluering af fagområder 2008 [The Science and Technology Domains within Htx and Stx Gymnasium]. Danmarks Evalueringsinstitut, The Danish Evaluation Institute. (in Danish)

Dillon, D. R., Obrien, D. G., Moje, E. B., \& Stewart, R. A. (1994). Literacy Learning in SecondarySchool Science Classrooms - A Cross-Case Analysis of 3 Qualitative Studies. Journal of Research in Science Teaching, 31, 345-362.

Dillon, J. (2009). On Scientific Literacy and Curriculum Reform. International Journal of Environmental \& Science Education, 4, 201-213.

Donnelly, J. F. (1999). Interpreting differences: the educational aims of teachers of science and history, and their implications. Journal of Curriculum Studies, 31, 17-41.

Driver, R., Leach, J., Millar, R., \& Scott, P. (1996). Young peoples images of science. Open University Press.

Ernest, P. (1989). The Impact of Beliefs on the Teaching of Mathematics. In P.Ernest (Ed.), Mathematics Teaching: The State of The Art (pp. 249-254). London: Falmer Press.

Godfrey-Smith, P. (2003). Theory and reality: an introduction to the philosophy of science. Chicago: University of Chicago Press. 
Hurley, M. H. (2001). Reviewing integrated science and mathematics: the search for evidence and definitions from new perspectives. School Science and Mathematics, 101, 259-268.

Koballa, T. R., Graber, W., Coleman, D. C., \& Kemp, A. (2000). Prospective gymnasium teacher's conceptions of chemistry learning and teaching. International Journal of Science Education, 22, 209-224.

Krogh, L. B. (2006). 'Cultural Border Crossings' i fysikundervisningen - et kulturelt perspektiv på unges forhold til fysik' [Cultural Border Crossings within the Physics Classroom - a cultural perspective on youth attitudes towards physics]. Steno Department for Studies of Science and Science Education.(in Danish)

Langer, J. A. \& Applebee, A. N. (1988). Speaking of Knowing: Conceptions of Learning in Academic Subjects. Academic Learning in High School Subjects. Washington: Office of Educational Research and Improvement.

Lotter, C., Harwood, W. S., \& Bonner, J. J. (2007). The Influence of Core Teaching Conceptions on Teachers' Use of Inquiry Teaching Practices. Journal of Research in Science Teaching, 44, 1318-1347.

Magnusson, S., Krajcik, J., \& Borko, H. (1999). Nature, Sources, and Development of Pedagogical Content Knowledge for Science Teaching. In J.Gess-Newsome \& N. Lederman (Eds.), Examing Pedagogical Content Knowledge: The Construct and its Implications for Science Education (pp. 95-132). New York: Kluwer Academic Publishers.

Marton, F. \& Booth, S. (1997). Learning and awareness. Mahwah, NJ: Erlbaum.

Mellado, V. (1998). The classroom practice of preservice teachers and their conceptions of teaching and learning science. Science Education, 82, 197-214.

Meyer, H., Tabachnick, B. R., Hewson, P. W., Lemberger, J., \& Park, H. J. (1999). Relationships between prospective elementary teachers' classroom practice and their conceptions of biology and of teaching science. Science Education, 83, 323-346.

Pillay, H. (2002). Understanding Learner-centredness: does it consider the diverse needs of individuals? Studies in Continuing Education, 24, 93-102.

Roberts, D. A. (1988). What counts as science education? In P.Fensham (Ed.), Development and Dilemmas in Science Education (pp. 27-54). London: Falmer Press.

Säljö, R. (1979). Learning in the learner's perspective (I). Some common-sense conceptions Gothenburg: Department of Education, University of Göteborg.

Shulman, L. (1986). Those Who Understand: Knowledge Growth in Teaching. Educational Researcher, 15, 4-14.

Sjøberg, S. (2005). Naturfag som almendannelse - en kritisk fagdidaktik [School Science as Bildung - A Critical FachDidaktik]. Aarhus: Klim (In Danish).

Tsai, C. C. (2002). Nested epistemologies: science teachers' beliefs of teaching, learning and science. International Journal of Science Education, 24, 771-783.

Tsai, C. C. (2007). Teachers' scientific epistemological views: The coherence with instruction and students' views. Science Education, 91, 222-243. 